\title{
The Brazilian states and the Federal Social Assistance System: state capacity-building in Maranhão and São Paulo
}

\author{
FABIANA TOCK ${ }^{1}$ \\ EDUARDO JOSÉ GRIN ${ }^{1}$ \\ LAURO GONZALEZ ${ }^{2}$
}

\author{
${ }^{1}$ Fundação Getulio Vargas (FGV EAESP) / Escola de AdMinistração de EMPresas, SÃo Paulo - SP, Brazil \\ 2 Fundação Getulio Vargas (FGVcemif) / CEntro de Estudos em MicrofinançAS E InClusÃo Financeira, SÃo Paulo - SP, BRAZIL
}

\begin{abstract}
This article is part of a set of studies seeking to understand the implications of federative design in public policies. The unit of analysis adopted is the national public policies systems. The studies suggest the importance of gradual and continued strengthening of state capacities of subnational governments to implement policies. Several articles investigate the relationship between federalized systems and state capacity-building in local governments. However, little is known about how this relationship occurs in state governments. This research investigated how the Brazilian Sistema Único de Assistência Social (SUAS) (Federal Social Assistance System) affects the capacity of state governments to implement policies and analyzed the program of eradication of child labor in the states of Maranhão and São Paulo. We sought to explain how the combination of SUAS institutional characteristics and the structural, institutional, and political conditions present in these states have regulated or built state capacities. The results indicate that these conditions were decisive for state capacity-building and, above all, show the role played by the Brazilian state governments in SUAS.
\end{abstract}

Keywords: Federalism. Sistema Único de Assistência Social. State capacity-building. State governments.

\section{Os estados e o Sistema Único de Assistência Social: construção de capacidades estatais nos governos do Maranhão e de São Paulo}

\section{Resumo}

Este artigo se insere no conjunto de estudos que buscam compreender as implicações do desenho federativo nas políticas públicas, adotando como unidade de análise os sistemas nacionais de políticas públicas. Emerge dos diversos estudos a importância do fortalecimento gradativo e continuado das capacidades estatais dos governos subnacionais para implementar políticas. Diversos trabalhos investigam a relação entre os sistemas federalizados e o desenvolvimento de capacidades estatais nos governos locais, entretanto, pouco se sabe como ocorre essa relação nos governos estaduais. Esta pesquisa investigou como o Sistema Único de Assistência Social (SUAS) afeta as capacidades dos governos estaduais de implementar políticas. Com este fim, analisou o Programa de Erradicação do Trabalho Infantil (PETI) nos estados do Maranhão e de São Paulo. Buscou-se explicar como a combinação entre as características institucionais do SUAS e as condições estruturais, institucionais e políticas presentes nestes estados regulou ou possibilitou a criação de capacidades estatais. Os resultados apontam que tais condições foram determinantes na construção de capacidades e, sobretudo, informam a respeito do papel assumido pelo governo do estado no SUAS

Palavras-chave: Federalismo. Sistema Único de Assistência Social. Capacidades estatais. Governos estaduais.

\section{Los estados y el Sistema Unificado de Asistencia Social: creación de capacidad estatal en los gobiernos de Maranhão y São Paulo}

\section{Resumen}

Este artículo es parte del conjunto de estudios que busca comprender las implicaciones del diseño federativo en las políticas públicas y adopta como unidad de análisis los sistemas nacionales de políticas públicas. De los diversos estudios surge la importancia del fortalecimiento gradual y continuo de las capacidades estatales de los gobiernos subnacionales para implementar políticas. Varios estudios investigan la relación entre los sistemas federalizados y el desarrollo de la capacidad estatal en los gobiernos locales, sin embargo, se sabe poco acerca de cómo se produce esta relación en los gobiernos de los estados. Esta investigación averiguó cómo el Sistema Unificado de Asistencia Social (SUAS) afecta las capacidades de los gobiernos estatales para implementar políticas y, con este fin, analizó el Programa para la Erradicación del Trabajo Infantil en los estados de Maranhão y São Paulo. Se intentó explicar cómo la combinación de las características institucionales del SUAS y las condiciones estructurales, institucionales y políticas presentes en estos estados o reguló o posibilitó la creación de capacidades estatales. Los resultados indican que estas condiciones fueron cruciales en la creación de capacidades y, sobre todo, informan acerca del rol asumido por los gobiernos de los estados en el SUAS.

Palabras clave: Federalismo. Sistema Único de Assistência Social. Capacidades estatales. Gobiernos estatales. 


\section{INTRODUCTION}

It is widely acknowledged that federalism has strong implications for public policies; to understand them in the Brazilian context it is necessary to analyze the aspects that structured the decentralization process unfolding since 1988 and affecting sub-national governments' state capacities to implement a policy. Literature on the subject tends to address two complementary aspects: a) the federal government's preponderant role in social policy regulation designed to obtain more homogeneous results from their implementation by autonomous entities (ARRETCHE, 1996; BICHIR, 2011, 2016a; LICIO, 2012); b) a positive relationship between the institutional design of national public policy systems and the development of federated states' capacities in the sub-national spheres of government (BICHIR, 2011, 2016a; FRANZESE and ABRUCIO, 2013; GRIN, 2016).

This article investigates how national systems affect the state capacities of state governments to implement policies. To that end, in the ambit of the Unified Social Assistance System (Sistema Único de Assistência Social - SUAS) it analyzes state capacity building under the aegis of the Child Labor Eradication Program (Programa de Erradicação do Trabalho Infantil PETI) in the states of Maranhão and São Paulo

With the promulgation of the 1988 Federal Constitution a new federative arrangement took shape in Brazil: political, administrative and financial autonomy for the municipalities and the redistribution of federal resources to the sub-national spheres of government had important consequences for the conformation of a new institutional design in the field of public policies. The inductive role of the federal government was reinforced with a view to stimulating governments to adhere to national policies and to address the poor institutional and administrative capacity of those sub-national entities.

In alignment with that vision, the national public policy systems instituted a new administrative design with a view to qualifying federative cooperation. An important impact of logic of the national systems is the gradual and continued strengthening of state capacities of subnational governments to implement policies (BICHIR, 2011, 2016a; FRANZESE and ABRUCIO, 2013). By transferring resources associated to programs and the greater part of their management to those spheres of government, the systems create conditions for the emergence of a local bureaucracy favoring the strengthening of the sub-national sphere (FRANZESE and ABRUCIO, 2013).

In regard to the SUAS, apart from acknowledging that the constitutional rules delegated a residual role to the state governments, little is known "[...] about who implements social assistance policy in the state, or how the policy and the state resources invested in it are implemented" (SOUZA, 2018, p. 271). In their work, Silva (2015), Pereira (2016) and Souza (2018) have made important contributions to elucidating the state capacities of state governments to implement a national social assistance policy. The results of using distinct analytical categories show that there is a high degree of heterogeneity in the state capacities of the states in the ambit of the SUAS. That revelation, in turn, relativizes the idea that the national systems produce homogeneous effects in the sub-national entities (SILVA, 2015). What then can the explanation be for the differences constituting that heterogeneity and the variations among the Brazilian states' capacities?

This research set out to analyze certain variables that exist in the states which together with the institutional rules, processes and mechanisms of the SUAS made the creation of state capacities feasible. The investigation endeavored to examine the extent to which that process influenced the production of heterogeneity of the SUAS capacities among the states. The article is divided into three parts apart from this introduction and the conclusion. The first part presents the field of study of state capacities; the second the methodology adopted and the third, the results of the analysis, by means of a thematic and spatial slice methodology, of the constructed state capacities and the factors that contributed to building or regulating them.

\section{The National Public Policies Systems and the Construction of State Capacities}

Public policies systems have been studied in their aspect as an important resource for coordinating the different spheres of government in the decentralized type of federalism initiated in Brazil after 1988. The results of the systems have been to expand and improve service and program provision and generate conjunction with the national policy guidelines. Thus, the systems respond to the dual challenge of implementing the national agenda of universalizing social policies while at the same time resolving the dilemma of shared attributions foreseen in Article 23 of the 1988 Federal Constitution (FRANZESE, 2010).

The systems, however, depend on structures designed to stimulate adherence because the decision on the part of the sub-national entities to align themselves with the Federal norms is decisive for their success. In the post-constituent context, 
the low sub-national state capacity underscored the need to construct federal induction strategies with a view to encouraging adherence and ensuring at least minimum levels of policy implementation (ARRETCHE, 1999; BICHIR, 2014, 2016a; $\mathrm{LICIO}, 2012)$. However, no provision was made for the development of sub-national state capacity and its absence intensified as decentralization proceeded over time and it eventually came to be inserted within the scope of federative cooperation initiatives.

Thus one important impact of the logic of the public policy systems has been the gradual and continued strengthening of the state capacities of subnational governments to implement policies (ABRUCIO, FRANZESE and SANO, 2013; BICHIR, 2016a; FRANZESE and ABRUCIO, 2013; GRIN and ABRUCIO, 2018). That is because the implementation of policies on a national scale makes demands on the Union's coordinating capacity and more than that, it depends on the institutional capacities of local governments to meet the demands of municipalization (BICHIR, 2011). The quality of service provision and policy results depend on mechanisms designed to develop local administration and guarantee compliance with the rules and minimum standards of implementation.

In regard to that challenge, in addition to allocating resources for effective service provision, the public policy systems condition their transfers to the existence of councils, shared funds and specific sector plans in the sub-national governments. The transferal not only of resources associated to programs but the greater part of their respective administration to those spheres of government created conditions for the emergence and strengthening of a local bureaucracy (FRANZESE and ABRUCIO, 2013). It is reasonable to assume, therefore, that designs of the public policy systems operate within a framework of measures and regulations aimed at obtaining state capacity development at the sub-national level (BICHIR, 2011, 2016a; GRIN and ABRUCIO, 2018).

In the literature, the concept of state capacities, albeit imbued with a plurality of meanings, is used as an analytical tool to gain an understanding of the State's different policy results, means of verification and purpose of application. The greatest efforts to define the term precisely are found in those studies with state-centered approach typical of the late 1970s which, instead of seeing the State as a space for accommodating the interests of social groups, began to see it as an actor capable of formulating and seeking to achieve its own objectives. The seminal work Bringing the State Back In (1985) addresses the mechanisms and regimes that confer the power of agency and capacity for autonomous action on the State.

Authors affiliated to that line (EVANS, 1993, 2003; EVANS and RAUSCH, 2014; GEDDES, 1994; SKOCPOL, 1985) took up the Weberian perspective once more, arguing that it was possible to explain the action of the State in terms of its constitutive characteristics; that is, by getting to know the organizational structures that influence its powers of agency. In that perspective, the concept of state capacities is related to governments' autonomy and the resources they have with which to implement their policies (SKOCPOL, 1985). Thus, the concept can serve as an explanatory variable for the state's efficiency and efficacy in the achievement of its objectives.

The State-centered vision is supported on Weber's idea of bureaucracy, understood to be a rationally organized structure based on preferences and interests that are endogenous to the bureaucrats. Not by chance, that is the point of departure for various studies that have endeavored to prove the effects of state capacities on social and economic development.

The turn of the century saw the advent of new analytical focuses on internal policy arrangements as determinants of governments' capacity for action. Nevertheless, the respective literature maintains the usual attribution of importance of governments capacity for action for the implementation of their policies. In spite of the partial consensus regarding that theoretical stance, there is far less consensus regarding the definition of constitutive dimensions and the possible operative variables of that concept (BOWMAN and KEARNEY, 1988; CINGOLANI, 2013; GOMIDE, PEREIRA and MACHADO, 2018; GRIN, 2012).

A variety of empirical studies have been disseminated that address state capacities in different policy areas. Some authors suggest that precisely because the democratic context requires an expansion of the State's articulatory and interlocutory capacities, the development of technical-administrative capacities is more vital than ever (GRIN, 2012, 2016; KJAER, HANSEN and THOMSEN, 2002; SKOCPOL and FINEGOLD, 1982). Along those lines the preferential focus in the case of Brazilian studies has been on administrative-bureaucratic capacities.

The state-centered approach to state capacities (CINGOLANI, 2013) underscores the importance of organizational capacity and of the Weberian-type professional bureaucracies made up of civil servants recruited on the basis of meritocratic criteria (EVANS and RAUSCH, 2014; GEDDES, 1994; OLSEN, 2006; SIKKINK, 1991; SKOWRONEK, 1984). In that perspective, the State could achieve its goals if it were endowed with key resources such as qualified staff and financial resources to expand the 
efficacy of its actions in society (SKOCPOL, 2002). Thus, one way of investigating state capacities would be to identify those organizational structures whose absence or presence is critical for enabling governments to carry out their tasks (EVANS, RUESCHMEYER and SKCOPOL, 2002).

Developing capacities means increasing government efficiency and response capacity and that requires the reinforcement of technical, administrative and managerial competence. Policy implementation is supported on the development of those capacities; in other words, it is based on the strengthening of institutional infrastructure (GRINDLE, 1997; SIKKINK and WOLF, 1993). That is why one of the basic axes of state-centered approaches is that state structures can constitute valid explanatory variables for the purpose of analyzing government actions (CINGOLANI, 2013). Along those lines, this article will consider two aspects of state capacities: organizational resources, and management and articulation strategies and they have been divided into six variables as shown in the next section.

\section{METHODOLOGY}

This work used qualitative methods for data gathering and analysis and multiple case studies of the polar type considering that extreme situations have better potential for revealing contrasting patterns. The study selected the states of São Paulo and Maranhão and a single public policy, the PETI, because of its theoretical importance. It is a program with attributes and characteristics that make it a suitable choice for in-depth analysis (EISENHARDT, 1989).

Data gathering was carried out in two stages. The first was done by means of an analysis of the documents that compose the program's legal-regulatory framework, the infra-constitutional acts, operational instructions and the three volumes of the PETI. That made it possible to elaborate an analytical narrative of the trajectories of the SUAS and the PETI, exploring legal aspects and regulatory alterations that were made in the course of time and which could have involved the development of state capacities.

The second stage involved holding in-depth interviews with actors associated administration and with technical staff of the Social Development Departments of the respective state governments. Six interviews were held in the state of São Paulo and ten in the state of Maranhão. The interviewees were selected according to their positions and attributions, that is, what they did or still do within the sphere of the program.

Observations were made to detect the presence or absence of six variables in the organizational structures of those states; variables that express the existence of state capacities. A set of empirically observable indicators identified in the literature on state capacities was associated to each variable.

However, the mere existence of those variables in the interior of the State cannot be interpreted as being synonymous with capacities (EVANS, RUESCHMEYER and SKOCPOL, 1985), because it may be that, in practice, those resources and competences are not mobilized or transformed into actions (GOMIDE, PEREIRA and MACHADO, 2018). Thus, once the presence of a variable had been identified, it was also observed how it organized itself in the contact with the rules, mechanisms and processes constituted by the SUAS and how it became transformed into effective state action, making the creation of capacities feasible. There now follows a presentation of the selected variables and the indicators used to measure them. 
Box 1

Systematization of the variables used to identify technical-administrative capacities

\begin{tabular}{|c|c|c|c|}
\hline Author & Variable & Description & Indicator \\
\hline $\begin{array}{l}\text { Skocpol (1985), } \\
\text { Grindle (1996), } \\
\text { Gomide and } \\
\text { Pires (2014) }\end{array}$ & Bureaucratic quality & $\begin{array}{l}\text { Qualified bureaucracy: } \\
\text { presence of a bureaucracy } \\
\text { with Weberian characteristics }\end{array}$ & $\begin{array}{l}\text { 1. Type of employment bond/contract } \\
\text { and existence of career plan; } \\
\text { 2. Merit-based recruitment plan; } \\
\text { 3. Professional qualification in compliance with the } \\
\text { Basic Human Resources Operational regulations (Norma } \\
\text { Operacional Básica de Recursos Humanos [NOB]-RH) } \\
\text { and the rules governing bureaucratic professionalization } \\
\text { (technical and administrative mastery). }\end{array}$ \\
\hline $\begin{array}{l}\text { Grindle (1996) } \\
\text { Gomide and } \\
\text { Pires (2014) }\end{array}$ & $\begin{array}{l}\text { Availability of financial } \\
\text { resources }\end{array}$ & $\begin{array}{l}\text { Capacity to obtain revenue and } \\
\text { control of public expenditure }\end{array}$ & $\begin{array}{l}\text { 1. Policy financing stability; } \\
\text { 2. Local/autonomous resources invested in the program; } \\
\text { 3. Execution index (ratio of total spending } \\
\text { on the program, to the total volume of financial } \\
\text { resources transferred by the Ministry of Social } \\
\text { Development, for program execution). }\end{array}$ \\
\hline Grindle (1996) & $\begin{array}{l}\text { Agenda centrality in the } \\
\text { organizational structure }\end{array}$ & $\begin{array}{l}\text { Institutional stance of the } \\
\text { program evaluated by the } \\
\text { allocation of human, financial } \\
\text { and technological resources }\end{array}$ & $\begin{array}{l}\text { 1. Bureaucratic quality; } \\
\text { 2. Local/autonomous resources } \\
\text { invested in the program. }\end{array}$ \\
\hline Mann (1984) & $\begin{array}{l}\text { Territorial outreach and } \\
\text { action capillarity }\end{array}$ & $\begin{array}{l}\text { Capacity to mobilize institutions } \\
\text { and take advantage of } \\
\text { existing bureaucracies at local } \\
\text { government level for the } \\
\text { implementation of actions }\end{array}$ & $\begin{array}{l}\text { 1. Territorial outreach of the actions; } \\
\text { 2. Bureaucratic strengthening for } \\
\text { institutions involved in implementation. }\end{array}$ \\
\hline $\begin{array}{l}\text { Gomide and } \\
\text { Pires (2014) }\end{array}$ & $\begin{array}{l}\text { Existence and } \\
\text { operation of inter and } \\
\text { intra-governmental } \\
\text { coordination } \\
\text { mechanisms }\end{array}$ & $\begin{array}{l}\text { Presence of bureaucracy with } \\
\text { great capacity for articulating } \\
\text { interests and engaging actors for } \\
\text { the implementation of actions }\end{array}$ & $\begin{array}{l}\text { 1. Coalitions articulated around defined goals; } \\
\text { 2. Presence of multiple organizations and different } \\
\text { bureaucracies implicated in the policy design; } \\
\text { 3. Existence of coordination instruments. }\end{array}$ \\
\hline Pedroti (2014) & $\begin{array}{l}\text { Planning control and } \\
\text { management processes }\end{array}$ & $\begin{array}{l}\text { Control and management } \\
\text { support solutions developed } \\
\text { within the program's scope }\end{array}$ & $\begin{array}{l}\text { 1. Existence of management instruments (management } \\
\text { protocols, improvement agreements, etc.). }\end{array}$ \\
\hline
\end{tabular}

Source: Elaborated by the authors.

It is worth remembering that the Federal Government instituted the PETI in the state of Mato Grosso do Sul in 1996 and in 2001 expanded it to all the other states. The program consists of: (i) income transfer; (ii) provision of socio-educational services for children and adolescents in labor situations; and (iii) support for the families. It has a nation-wide outreach and its actions are implemented in a decentralized manner respecting the attributions of each federal entity. In 2005, the program was integrated to the SUAS and since then it has been supported by that system's administrative and financial mechanisms and its spheres of articulation and pact formation. At that time the income transfer component was integrated to the Bolsa Familia Program (PBF) and in 2013 the socio-educational component was incorporated to the Sociability and Bond Strengthening Service (Serviço de Convivência and Fortalecimento de Vínculos - SCFV).

In 2014, in response to the new child labor scenario revealed by the 2010 census conducted by the Brazilian Geography and Statistics Institute (Instituto Brasileiro de Geografia and Estatística - IBGE), the program underwent a redesigning process intended to develop strategic actions (AEPETI). It sought to boost the confrontation of child labor by articulating social assistance services, inter-sector actions, interlocution with the justice system, control bodies and civil society. It is important to point out that the redesigning of the PETI sought to improve the program's management model and it represents a feasible milestone for analyzing how state capacities were created prior to the redesigning and after it.

Thus this work sets out to observe the state capacity building processes in the PETI in two distinct phases: from the time of its integration to the PBF up until the time of the reorganization of the SCFV (2005 to 2013); and from the redesigning of the PETI 
starting in 2014 up until the beginning of the AEPETIs in 2018. Based on that methodological construction with its variables and indicators, the next section analyzes whether the presence or absence of the selected variables in the two periods was associated to the building of state capacities in the two states.

\section{Analysis of the Variables Indicative of State Capacities}

Authors with a state-centered approach underscore that the foundation for state action capacity is the existence of a highly qualified bureaucracy (EVANS, 1993, 2003; EVANS and RAUSCH, 2014; GEDDES, 1994; SKOCPOL, 1985). Nevertheless, analyzed with the Weberian rational lens, there is consensus that it is associated to the expansion of the state's capacity to take action in pursuit of its objectives. In that perspective, indicators of a qualified bureaucracy and examples of attributes capable of constructing a reliable staff of professionals would be: merit-based recruitment, long-term career structuring and technical qualification (SKOCPOL, 1985). In some studies, the quality of the bureaucracy is equated with the professionalization of key areas of government and the and associated indicators are technical and managerial mastery (GRINDLE, 1996; EVANS, 1995).

In Maranhão, prior to the redesigning of the PETI, the human resource framework presented low bureaucratic quality and reduced implementation capacity, except for the period immediately after the integration to the PBF. Even though recruitment had been via competitive public entry exams and the salaries had been compatible with those of other government divisions, there was: a low level of technical qualification (the specific career does not demand a university qualification), no possibility of professional ascension, no definition of salary and responsibility frameworks, and promotions depended on political indications. Also, there was a visible ageing of the staff and staff numbers were insufficient to develop the social assistance policy in conformity with the NOB/RH.

Immediately prior to the redesigning, the small number of civil servants available in the Social Development Department led to a deacceleration of program activities and, later, to its voidance. The low quality of the bureaucracy persisted in the aftermath of the redesigning as exemplified by the contracting of staff on a temporary basis and the lack of a structured career plan; however, there was an amplification of capacity for plan implementation. The change of government led to changes in the department's administrative staff and top positions of authority were filled by persons with a trajectory of active engagement in defense of the SUAS and the social assistance policies. Within a few months, a partnership arrangement had been established with the International Labor organization (ILO) to make a diagnosis of the situation in regard to child labor in the state's municipalities. Furthermore, the state government initiated the elaboration of the Project for the Strengthening and Execution of the PETI Strategic Actions in the State (Projeto de Fortalecimento and Execução das Ações Estratégicas do PETI no estado), with a view to capacitating and advising the municipal technical teams and conducting awareness raising and mobilization campaigns.

Analysis of the respective period suggests that other factors affected the state capacities apart from the qualification of the bureaucracy in the terms suggested above. From the interviews it could be seen that the activism of the department's top-level staff was decisive for the expansion of capacity to implement the PETI in the state. Furthermore, some elements that are not determined by the SUAS also fostered the production of state capacities.

In the case of São Paulo, it was found that the advent of the redesigning produced a significant change in the bureaucratic quality indicators. The presence of a stable qualified bureaucracy was identified albeit some key aspects of the Weberian model were absent such as: technical staff with a career that was specifically in the ambit if the SUAS, recruited via competitive public entrance exams and with a qualification compatible with the NOB/RH and in addition, the salaries were low and there were no structured career plans for clearly defined posts.

There was a high degree of rotativity of heads of department and ideological cleavage due to the tardy incorporation of specific SUAS careers to the department's administrative framework. The program's technical team and coordinator however, remained in place throughout the two analyzed periods so that continuity of the activities was preserved. However, it must be pointed out that, given the scenario of constant institutional instability, the reaction of the program's bureaucracy endowed it with some degree of insulation. That reality meant there was a growing increase in bureaucratic professionalization with technical mastery and a considerable degree of administrative capacity which, in turn led to the continued implementation of the actions. Thus, in that case, when they were put into effect, the attributes present in the bureaucratic organization of the state influenced the building of state capacities. 
In addition to the aspect of bureaucratic quality, the literature emphasizes the importance of financial capacity: the state's authority to obtain revenue and control the application of public expenditure. Various authors highlight that component as being a suitable parameter for measuring technical-administrative capacities: greater revenue from taxes is associated to an elevation of the expected level of administrative capacity (KJAER, HANSEN and THOMSEN, 2002; SKOCPOL, 1985). Based on Grindle (1996) and Gomide and Pires (2014), the study used three indicators to observe financial capacity: the policy's financial stability, executor's own resources invested in the program and the policy execution index - the ratio between the total amount spent by the program and the total amount transferred by the MDS for its execution.

No significant financial capacities were identified in Maranhão. Despite the stability acquired for financing PETI actions after the redesigning, there was no evidence of any increase in technical capacity associated to budget planning neither was there any improvement in the generation of autonomous income or in the policy execution index for which the last year of the period was most representative.

In the case of São Paulo there is an observable diversity of situations. In the first decade of program execution there were important attributes present related to financial capacity. In particular, the absence of financial resources exclusively dedicated to the PETI did not lead to the sub-execution of program actions; quite the contrary, it led the coordinating body responsible for the program to seek alternative ways of financing them. Given that the Department of the São Paulo government shares the coordination of the program with the PBF, many of the actions carried out in the first period made use of resources of the Bolsa Familia Decentralized Administration Index (Índice de Gestão Descentralizada do Bolsa Família - IGD-PBF), and, when the actions were joint actions, funds from the Pro-Jovem program. The program also managed to capture resources from other institutional actors mobilized around that agenda. Thus, despite the lack of stability in policy financing and of autonomous resources being invested, there was an effective capacity to obtain income and execute the resources obtained.

That scenario changed after the redesigning and it became more like the one in Maranhão; in spite of the stability acquired for the financing of the PETI there was no increase in technical capacity associated to the budget planning and no improvement in generating intrinsic resources or in policy execution with the exception of the last year of the period. The difficulty in making full use of the federal funding in the first years after the redesigning was associated to an austerity policy on the part of the state and the consequent cancelling of activities foreseen for the 2015-16 two-year period. Another influence on the results was the divergence in the understandings of program possibilities on the part of the coordinating body and the new head of department.

Here, once more, it can be seen that capacity building was more related to the program's insertion in the organizational structure of the Department, a protagonist in those inter-institutional spheres addressing the issue such as the São Paulo Forum for the Eradication of Child Labor (Fórum Paulista de Erradicação do Trabalho Infantil), than to the actual federal policy for financing the program.

The third variable that was analyzed, the centrality of the agenda, can be taken as a proxy for the technical capacities, especially in regard to the availability of human and financial resources (GRINDLE, 1996). It concerns the proximity between the agenda of a given policy and the organizational structure of its department of origin and the same time to the broader context of the respective government. Agenda centrality favors the formation of a qualified bureaucracy and the allocation of financial resources for maintaining a given policy (GRINDLE, 1996). In the State of Maranhão, in the period immediately after the program's integration to the PBF, the program gained an outstanding position in comparison with the other SUAS programs because of its model of federal co-financing with the municipalities. The volume of financial resources invested at the local level led to an intensification of the state department's actions and was able to count on almost all the technical staff in posts of coordination in the origin of the program for its implementation. However, towards the end of the years 2000, it began to lose centrality as other SUAS programs such as the PBF gradually became consolidated.

In more recent years there has been a visible intensification of the (financial and eventually, institutional) dispute between the government programs and those offered by the SUAS. At the same time there has been no observable favoring of the PETI in the allocation of human or financial resources. It can be safely said that the former centrality of the agenda in the organizational structure was associated to the outstanding position the program enjoyed compared to the other SUAS programs and that was largely due to the federal co-financing with the municipalities.

The centrality of the PETI agenda in the organizational structure of the São Paulo government department was very different from that in Maranhão. There was no identifiable relationship either between the centrality of its agenda and its status in comparison with the other SUAS programs or government actions or between that centrality and technical capacity building 
during the first of the analyzed periods. The second period however, reveals that the intervention of the Justice system in the control of that public policy together with the availability of financial resources stemming from the federal government's financing of the AEPETIs endowed the program, once more, with greater visibility within the structure of the department. In 2016 the Office of the Public Prosecutor (OPP) of the State of São Paulo installed a public civil inquiry to investigate the conduct of the state government regarding the elaboration of the PETI.

Although it is not a compulsory instrument of the PETI, the investigation came in the wake of a broad mobilization unfolded by the OPP to monitor the elaboration of the municipal thematic plans. Following that a discussion was commenced within the department for the purpose of elaborating the respective state plan and later an Inter-sector Commission was instituted to elaborate and execute the said plan. Elaboration of that instrument began in 2018 by means of public hearings. It can be said that the that the OPP's activism and the availability of funds in account where what guaranteed the centrality of that agenda in the department's organizational structure. As a result, a series of actions was implemented that led to the expansion of the team's technical capacity in aspects such as articulation and management and they will be presented in greater detail later in the text. However, the centrality of the agenda in that period did not influence the indicators used by the study, such as human resources or financial resources, to any observable extent.

Another important variable in regard to technical-administrative capacities concerns the state's skill in mobilizing its institutions and making best use of existing bureaucracies at the local government level. In that approach, the greater the territorial outreach or, as Mann (1984) put it, the greater the infrastructural power, the more developed state capacities such as coordination and administration are. According to the literature (BICHIR, 2016a; COUTINHO, 2014; SOUZA, 2017), the territorial outreach can be measured by the existence of institutions involved in implementation - which configures a bureaucratic reinforcement or by the simple territorial coverage of the actions. Even though the Department of the Maranhão State government could not count on a decentralized organizational structure, there was increasing territorial coverage of the PETI actions in the second of the analyzed periods. The increment in the capacity of the coordinating body responsible for program execution was a consequence of the actions carried out in the ambit of the advice and technical support provided to the municipalities in loco. Those initiatives drew the state administration and the municipalities closer together and boosted the municipal participation in the Maranhão State Forum for the Prevention and Eradication of Child Labor. That combination resulted in greater territorial coverage of the Department's action and made it possible for the other bodies participating in the forum to benefit from the same bureaucratic reinforcement for the implementation of their own actions

In the case of São Paulo, apart from the decentralized structure of the State Department, which has 26 regional boards (directorates) each with its own team responsible for all the pertinent services, the strong institutional quality of the network of actors external to the assistance itself but engaged with the child labor agenda contributed towards the effectiveness of the actions' territorial outreach. Thus, it was apparent that the work that the network had carried out for decades in the municipalities and equally that of the actors of the justice system favored the institutionalization of that agenda at the local level and, consequently, the adherence of that level of government to the federalized programs.

The last two variables studied in this work are associated to bureaucratic capacities: coordination (articulating interests and engaging actors in a synergic manner for the implementation of their actions) and administration (processual-organizational capacities) (GOMIDE and PIRES, 2014; PEDROTI, 2014). Both can be observed via the technical-administrative apparat that sustains a policy as for example: coalitions articulated around defined goals, the presence of multiple organizations and distinct bureaucracies inserted in the policy design, and the operation of institutional instruments of support for the implementation of the actions (GOMIDE and PIRES, 2014; PEDROTI, 2014). Thus, coordination and administration instruments are strategic organizational resources

Coordinating instruments constitute the institutional engineering of public policy systems. The need to guarantee a policy's national implementation in compliance with at least minimum parameters of execution requires the development of coordination mechanisms to promote regulation and induce local actions in convergence with the national guidelines. Administration instruments can also be understood as being within the ambit of coordination (PEDROTI, 2014). Along those lines, instruments such as municipal plans, administration protocols, improvement pacts, accountability mechanisms and others all seek to support policy implementation. Their elaboration invariably involves the participation of distinct bureaucracies in the three spheres of government so that in addition to the achievement of administrative objectives they also involve coordination strategies.

In Maranhão, the study identified the existence of a vigorous coordination strategy in the post-redesigning period that sought to obtain greater convergence with the actions of other government bodies. Even though it was not accompanied by the use of coordinative instruments, it resulted in the construction of technical capacities. After the redesigning there was a complete 
remodeling of the articulation with other actors of the justice system and with participants in the state forum. That was made possible by the adoption of an intra-governmental strategy supported by two factors: (i) the development of the program's own actions in articulation with other government bodies, and (ii) making use of the territorial outreach achieved by the advisory activities to support the implementation of the actions of other government bodies.

Another aspect observed was the new pattern of relationship between the program coordination and the central actors of this agenda such as the Regional Labor Inspectorate (Superintendência Regional do Trabalho - SRT), state government departments of health and of human rights, the Office of the State Public Prosecutor and others. As a result, the capacity of the department's bureaucracy to articulate a variety of different interests around the state project was increased and so was its degree of technical mastery and professionalization. Furthermore, the coordinative strategy that the department implemented forged the territorial outreach capacity of other government bodies and agencies. In regard to this last operation, it can be seen that there was a trade-off between the department, which gained facility for mobilizing its agenda, and the bodies participating in the forum which acquired capillarity for their actions.

Unlike the case of Maranhão, the activities that the respective department coordinated in São Paulo did not lead to any change in the pattern of the relationship between the bureaucracy and the other actors involved in the agenda. The department adopted a coordination strategy that was largely concerned with maintaining the inter-institutional relationships constituted in years prior to the period under analysis in this study. It should be noted that the protagonist role of the coordinating body in São Paulo in regard to the child labor agenda, dates back to the emergence of the São Paulo Forum (Fórum Paulista) in 1999, taking the form of joint actions with the forum or undertaking protective actions to complement the activities of the Justice system prior to 2005.

In a similar configuration to the national one, this network (forum) combines the protagonist roles of Justice system entities with those of other different actors involved in promoting protective policies. That institutional configuration has effectively guaranteed positive results from the series of actions carried out by the São Paulo government's executive branch. Internally, the relationships established between the program coordination and the forum actors served to boost the team's interest at critical moments of change while, externally, they were of fundamental importance in guaranteeing the amplitude of the PETI actions in the state.

It cannot be distinctly affirmed, for the period under analysis that the coordinative activities led to any amplification of technical capacities. What can be observed is a gradual incrementation of those capacities with the implementation of the cycle of biannual regionalized workshops for municipal technical staff and the public hearings held for the elaboration of the state plan. In both cases, there was strengthening of capacity to articulate different actors and negotiate common interests to foster the offer of a formative curriculum and to construct consensus regarding the diagnosed problems. Despite the existence of a clearly defined strategy of permanent, horizontal coordination, there was no observable use of coordination instruments.

The solutions in the scope of the Maranhão program proposed for supporting planning, control and administration indicated the existence of technical capacities. After the redesigning, state capacities were amplified by using administrative instruments. The study identified the use of two such instruments associated to the coordinative function and to the expansion of technical capacities. Elaboration of the Municipal Action Plans guaranteed the enforcement of the MD norms and the in loco advisory service provision for the actions was the instrument that registered the measures that municipal teams needed to take and assumed as commitments on the part of the administrating body. That process successfully created a transparent routine which in most cases was cooperative on the part of the two spheres of government. Both instruments boosted the enforcement capacity of the Maranhão government department, guaranteed the municipalities' cooperation with the state project, and amplified the state's capacity to implement the policy.

In the case of São Paulo, the planning and administration processes also experienced an increase in technical capacities during the period analyzed. Planning activities followed the administrative patterns of the SUAS and the annual Action Plans were based on the MDS and PEAS guidelines and submitted to the State Council for approval. In addition to the rites that are part of the SUAS's institutionary configuration, the coordination team responsible for the program organized a highly engaged administrative routine. Up until the end of the last government's mandate, team coordination was in the hands of an administrator in tune with the requirements of the SUAS's new institutional culture. The administrator's performance was directed at promoting the conceptual basis needed to make the actions feasible within the framework of its policy and program principles. 
That commitment imparted various administrative routines to the team and supported the continuity of the PETI actions even during the changes the program underwent and the scenario of uncertainty that is characteristic of that department. Over the years the team improved its capacity to interpret the legislation and the infra-legal acts and its skill in absorbing and diffusing information regarding theme-related contents and problems. After the milestone event of redesigning however, there was an even more substantial amplification of technical capacities especially associated to the performance of activities associated to the regulatory framework inherent to the elaboration of the State plan. Those regulations require, among other things, due execution of public competitive tendering processes, coordination by the State Commission, the holding of public hearings, and the elaboration of the Plan itself. Invariably, those requirements demanded that the team should improve its administrative capacities.

\section{Comparison of the Case Results}

This research investigated how the SUAS affects State Governments' state capacities to implement social assistance policies. Public policy systems expect a certain degree of homogeneity in their implementation on a national scale: their rules, mechanisms and processes are the same for all the states (ARRETCHE, 1996; BICHIR, 2011, 2016a; LICIO, 2012). However, the study revealed considerable heterogeneity in that state government capacities in the ambit of the SUAS which effectively relativizes that perspective (PEREIRA, 2016; SILVA, 2015; SOUZA, 2018).

While it may be considered that the institutional characteristics of the SUAS are insufficient to explain the high diversity identified among the state government capacities, there other factors that condition the development of those governments' capacities to implement and manage the social assistance policy. That being said, this research revealed those variables present in the state governments, which together with the regulatory framework and the institutional design of the SUAS made possible or obligatory the creation of state capacities.

Firstly, as mentioned previously, the study discovered that the policy's institutional design is not, initially, the producer of state capacities. In the two cases studied the construction of those capacities depended on the presence of variables in the state's' interiors and, most notably, on the way they interacted with policy's normative framework. It was found that above all certain contextual conditions exogenous to the SUAS (institutional activism, the policy's position in the organizational structure and in relation to other government projects, the prior existence of spheres of coordination and external actors engaged in the policy) also conditioned the production of capacities in the ambit of the PETI.

In the case of Maranhão, the conditions that made it possible to construct state capacities were: (i) institutional activism, (ii) the policy's position in relation to the broader spectrum of the government project, (iii) the prior existence of horizontal coordination, and (vi) the use of inter-governmental coordination instruments.

It was observed that the technical capacities were constituted independently of the existence of a qualified bureaucracy, as explained earlier in this work. However, the existence of institutional activism in the higher echelons of the department's administration was a determinant factor in enabling capacity building. At a certain moment, the program gained outstanding visibility among the other SUAS initiatives due to the federal government's co-financing the municipalities, which generated a greater availability of human resources and expanded the department's capacity to implement the program. However, the intensification of the dispute between SUAS programs and the state government's own programs constrained the construction of capacities. Thus, the program's status on the government agenda operated as a capacity development regulator.

Another determinant of technical capacity incrementation was the scope and intensity of horizontal coordination that the Maranhão government department adopted. That was feasible because of the prior existence of entities administering policies correlated with the child labor agenda. Inter-governmental coordination was also vital for capacity production - provision of technical advisory service in loco for policy implementation - promoting the necessary operational consensus and amplifying its actions' territorial outreach. The adoption of institutional enforcement instruments also showed itself to be an important promoter of capacities.

In the Case of the São Paulo government, there were various conditions inherent to state capacities construction: (i) the instability of the institutional environment. (ii) the policy's insertion in the organizational structure, (iii) the policy's institutional quality of social assistance, and (iv) the activism of justice system actors.

The presence of Weberian bureaucratic attributes was not the only determinant of the construction of capacities, given that contingencies of the department's institutional framework contributed by endowing the team with a certain degree of 
'insulation' that favored the incrementation of state capacities. The insertion of the program in the organizational structure was a factor associated to the existence of financial capacity. Even if there had not been stability in policy financing, or investment of its own resources in the first period analyzed, the program was allocated in a strategic coordinating structure. That meant that, at the time, it appeared alongside some of the SUAS flagship programs enabling the joint planning and joint execution of resources. The construction of financial capacities was related more to the program's insertion in the department's organizational structure than to the federal norm for financing the program.

State capacities formation in the São Paulo program was also intrinsically related to the existence of an institutional network in which the weightiest state bureaucracies with no direct links with social assistance are concentrated. The origin of the child labor agenda made it possible to constitute a more calibrated institutional framework that was preponderant in what has become the system for guaranteeing the rights of children and adolescents and various actors of the justice system are its protagonists. That configuration has at least two positive implications for the conformation of capacities: it guarantees the stability of the actions during periods of adversity in the department's institutional environment; and the network performs as a regulator of the federative pact when federal incentives prove to be insufficient to induce the implementation of the AEPETIs, as witness the intervention of the State Public Prosecutor's Office in 2016.

It can also be said, in the light of the results, that state capacities are of a provisional nature Their constitution depends on a configuration that is not determined by the policy normative per se which means that they are present at some moments and not at others. A policy's institutional design may act as a capacity booster, but it does not necessarily guarantee its permanence, given that governments' internal conditions tend to oscillate. Thus, analytically speaking, it is necessary to go beyond the policy normative and consider its actual implementation to observe the permanence (or impermanence) of the capacities, as was done in this research.

As previously mentioned, in Maranhão after the PETI was integrated with the PBF it occupied an outstanding position among the SUAS programs and that expanded its capacity to implement the policy. After years with no increase in capacities within the scope of the program, there was a notable increment of technical resources with the implementation of the AEPETIs, as stock variables in the interior of the state were mobilized thereby expanding capacities. In that period there was greater financial capacity as measured by the rate of execution, of coordination and greater inter and intra-governmental coordination and management coordination, especially regarding enforcement which had previously been non-existent. In São Paulo, capacities oscillated less but on the other hand they proved to be transitory: financial capacities that existed in the first period were not maintained afterwards, there was a loss of autonomy on the part of the technocrats and of centrality in the decisionmaking process in the changeover from the last administration and that was a barrier to the mobilization of formerly present capacities. However, administrative capacities were reinforced after the elaboration of the State plan.

\section{CONCLUSIONS}

This research sought to review interpretations of the state governments' roles in the SUAS. As shown, the institution of the SUAS considerably altered the scenario of fragility characteristically present in the trajectory of social assistance. The SUAS delineated the contents of this policy, organizing social securities and human rights defense in the ambit of social assistance. Democratic mechanisms were adopted for decision making, there was a new operational design to induce adherence of the sub-national spheres in alignment with the new technical standards for policy implementation. However, as the literature points out, the SUAS delegated a role to the state entities centered on non-finalizing activities unattractive from the point of view of electoral calculations. Thus, it failed to establish a system of incentives strong enough to induce actions at that level of government (BICHIR, 2011, 2016b; FRANZESE, 2010; SILVA, 2015; SOUZA, 2018).

In the two case studies it was possible to observe that the institutional design in the ambit of the PETI informed the role that the state government could take on. In other words, the structural, institutional and political conditions inherent to each government when in contact with the set of norms of the federalized policy, can generate various operations implanted by state governments that permit the specification of their roles. The government of Maranhão obtained greater inductive importance and assumed centrality in the coordination and accompaniment of the municipalities and was able to influence the quality and adaptation of the local actions to the federal directives. In the case of São Paulo, the emphasis was on the adoption of a regionalized policy orientated for coordinating, regulating and structuring state actions supported by 
the bureaucratic capacity installed at that level. The role the states took on as co-adjuvants in the municipalization or facilitation of a regionalized policy is related to the capacities created to achieve better policy implementation.

If the construction of capacities depends on a configuration that is not previously and exclusively determined by the directives of a policy, then it is possible to infer that the role of a state government in a policy also depends on those conditions. Along those lines, factors such as institutional activism and the policy's position in the organizational structure and in relation to the government project are important and so are the prior existence of spheres of coordination, the institutional nature of the network of external actors engaged in the policy and other conditions. That means the set of norms determining the state's role is merely a point of departure: the importance of the states in the SUAS will change according to the arrangement that is defined in the implementation of each policy. It can be concluded that, in the ambit of the analyzed policy, the role of the state is not tacit but created according to the conditions inherent to each government and according to its state capacities. This research opens the way for investigation as to which state capacities are most decisive in bringing the state governments 'into the' of the system. 


\section{REFERENCES}

ABRUCIO, F. L.; FRANZESE, C.; SANO, H. Trajetória recente da cooperação e coordenação no federalismo brasileiro: avanços e desafios. República, Democracia e Desenvolvimento, contribuições ao Estado brasileiro contemporâneo, v. 10, p. 129-163, 2013.

ARRETCHE, M. T. S. O mito da descentralização: maior democratização e eficiência das políticas públicas. Revista brasileira de ciências sociais, v. 11, n. 31, p. 44-66, 1996.

ARRETCHE, M. T. S. Políticas sociais no Brasil: descentralização em um Estado federativo. Revista Brasileira de Ciências Sociais, v. 14 n. 40, p. 111-141, 1999.

BICHIR, R. Mecanismos federais de coordenação de políticas sociais e capacidades institucionais locais: o caso do Programa Bolsa Família. 2011. Doctoral Dissertation (Doctor Degree) - Programa de Pós-Graduação em Sociologia e Ciência Política, Instituto de Estudos Sociais e Políticos, Universidade do Estado do Rio de Janeiro, Rio de Janeiro, 2011.

BICHIR, R. Novas Agendas, Novos Desafios: Reflexões sobre as relações entre transferência de renda e assistência social no Brasil. Novos Estudos, n. 104, p. 111, 2016 a.

BICHIR, R. Novos instrumentos de coordenação federativa: reflexões a partir do Programa Bolsa Família. Revista Brasileira de Políticas Públicas e Internacionais, v. 1, n. 1, p. 49-78, 2016b.

BICHIR, R. Os mecanismos de coordenação federal do Programa Bolsa Família. Brasília, DF: MDS, Sagi, 2014.

BOWMAN, A. O. M.; KEARNEY, R. C. Dimensions of state government capability. Western Political Quarterly, v. 41, n. 2, p. 341-362, 1988.

CINGOLANI, L. The State of State Capacity: a review of concepts, evidence and measures. United Nations University - Maastricht Economic and Social Research Institute on Innovation and Technology (MERIT), 2013. (MERIT Working Papers, n. 2013-053). Available at: <https://www.merit.unu.edu/publications/working-papers/ abstract/?id=5017>. Accessed on: July 14, 2020.

COUTINHO, D. R. Entre eficiência e legitimidade: O Bolsa Família no desafio de consolidação do SUAS. In: GOMIDE, A. A.; PIRES, R. R. C. (Eds.). Capacidades Estatais e Democracia: Arranjos institucionais de políticas públicas. Brasília, DF: IPEA, 2014. p. 267-293.

EISENHARDT, K. M. Building theories from case study research. Academy of management review, v. 14, n. 4, p. 532-550, 1989.

EVANS, P. O Estado como problema e solução. Lua Nova: Revista de Cultura e Política, São Paulo, n. 28, p. 107-156, 1993.

EVANS, P. El hibridismo como estrategia administrativa: combinando la capacidad burocrática con las señales de mercado y la democracia deliberativa. Reforma y Democracia, n. 25, p. 7-32, 2003.

EVANS, P. B. Embedded autonomy: States and industrial transformation. Nova Jersey: Princeton University Press, 1995.

EVANS, P. B.; RAUSCH, J. E. Burocracia e crescimento: uma análise internacional dos efeitos das estruturas do Estado "weberiano" sobre o crescimento econômico. Revista do Serviço Público, v. 65, n. 4, 2014, p. 407-437.

EVANS, P. B.; RUESCHMEYER, D.; SKOCPOL, T. On the road toward a more adequate understanding of the State. In: EVANS, P. B.;
RUESCHMEYER, D.; SKOCPOL, T. (Orgs.). Bringing the state back in. Cambridge: Cambridge University Press, 1985. p. 346-366.

FARIAS C. A. P. (Orgs.). Federalismo e políticas públicas no Brasil. Rio de Janeiro: Editora Fiocruz, 2013.

FRANZESE, C. Federalismo cooperativo no Brasil: da Constituição de 1988 aos sistemas de políticas públicas. 2010. Doctoral Dissertation (Doctor Degree in Public Administration and Government) - Escola de Administração de Empresas de São Paulo, Fundação Getulio Vargas, São Paulo, 2010.

FRANZESE, C.; ABRUCIO, F. L. Efeitos recíprocos entre federalismo e políticas públicas no Brasil: os casos dos sistemas de saúde, de assistência social e de educação. In: HOCMAN, G.; GEDDES, B. (Eds.). Politician's Dilemma: building state capacity in Latin America. Los Angeles: University of California Press, 1994.

GOMIDE, A. D. A; PEREIRA, A. K.; MACHADO R. A. Burocracia e capacidade estatal na pesquisa brasileira. In: PIRES, R.; LOTTA, G.; OLIVEIRA, E. (Orgs.). Burocracia e políticas públicas no Brasil: interseções analíticas. Brasília, DF: IPEA: Enap, 2018. p. 85-104.

GOMIDE, A. D. A.; PIRES, R. Capacidades estatais e democracia: a abordagem dos arranjos institucionais para análise de políticas públicas. Brasília, DF: IPEA, 2014.

GRIN, E. J. Notas sobre a construção e a aplicação do conceito de capacidades estatais. Revista Teoria \& Sociedade, v. 20, n. 1, p. 149-178, 2012.

GRIN, E. J. Rotas federativas para a promoção de capacidades estatais municipais: uma análise da experiência brasileira. 2016. Doctoral Dissertation (Doctor Degree in Public Administration and Government) - Escola de Administração de Empresas de São Paulo, Fundação Getulio Vargas, São Paulo, 2016.

GRIN, E. J.; ABRUCIO, F. L. Quando nem todas as rotas de cooperação intergovernamental levam ao mesmo caminho: arranjos federativos no Brasil para promover capacidades estatais municipais. Revista do Serviço Público, v. 69, n. esp., p. 85-122, 2018.

GRINDLE, M. S. Challenging the State: crisis and innovation in Latin America and Africa. Cambridge, Inglaterra: Cambridge University Press, 1996.

GRINDLE, M. S. (Ed.). Getting Good Government: capacity building in the public sector of developing countries. Massachussetts: Harvard University Press, 1997.

KJAER, M.; HANSEN, O. H.; THOMSEN, J. P. F. Conceptualizing state capacity: Testing the Validity of Tax Compliance as a Measure of State Capacity. Gothenburg: University of Gothenburg, 2002. (Democracy, the State, and Administrative Reforms Research Report, n. 6).

LICIO, E. C. Para além da recentralização: os caminhos da coordenação federativa do Programa Bolsa Família (2003-2010). 2012. Doctoral Dissertation (Doctor Degree in Social Policy). Universidade de Brasília, Brasília, DF, 2012.

MANN, $M$. The autonomous power of the state: its origins, mechanisms and results. European Journal of Sociology/Archives européennes de sociologie, v. 25, n. 2, p. 185-213, 1984. 
OLSEN, J. P. Maybe It Is Time to Rediscover Bureaucracy. Journal of Public Administration Research and Theory, v. 16, n. 1, p. 1-24, 2006.

PEDROTI, P. M. Desenvolvimento e inclusão social: o caso do arranjo político institucional do Programa Nacional de Produção e Uso do Biodiesel. In: GOMIDE, A, A.; PIRES, R. R. C. (Eds.). Capacidades estatais e democracia: arranjos institucionais de políticas públicas. Brasília, DF: IPEA, 2014. p. 213-236.

PEREIRA, J. M. O papel reservado aos estados na gestão descentralizada do Programa Bolsa Família: desafios e oportunidades. 2016. Doctoral Dissertation (Doctor Degree) - Universidade Federal do Rio de Janeiro, Rio de Janeiro, 2016.

SIKKINK, K. Ideas and institutions: Developmentism in Brazil and Argentina. Ithaca and London: Cornell University Press, 1991.

SIKKINK, K.; WOLFSON, L. Las capacidades y la autonomia del Estado en Brasil y la Argentina: un enfoque neoinstitucionalista. Desarrollo Económico, v. 32, n. 128, 1993. p. 543-574.

SILVA, A. L. N. D. Os estados no Suas: uma análise da capacidade institucional dos governos estaduais na assistência social. 2015.
Master Thesis (Master Degree) - Universidade Federal do Rio Grande do Norte, Natal, 2015.

SKOCPOL, T. Bringing the state back in: strategies of analysis in current research. In: EVANS, P. B; RUESCHMEYER, D.; SKOCPOL, T. (Orgs.). Bringing the state back in. Cambridge: Cambridge University Press, 1985. p. 3-38.

SKOCPOL, T.; FINEGOLD, K. State capacity and economic intervention in the early New Deal. Political Science Quarterly, v. 97, n. 2, p. $255-$ 278,1982

SKOWRONEK, S. Building a new American state. Cambridge: Cambridge University Press, 1984.

SOUZA, C. Federalismo e capacidades estatais: o papel do estadomembro na política de assistência social. In: PIRES, R.; LOTTA, G.; OLIVEIRA, E. (Orgs.). Burocracia e políticas públicas no Brasil: interseções analíticas. Brasília: IPEA: Enap, 2018. p. 289-297.

SOUZA, C. Modernização do Estado e construção de capacidade burocrática para a implementação de políticas federalizadas. Revista de Administração Pública, Rio de Janeiro, v. 51, n. 1, p. 27-45, 2017.

Fabiana Tock

ORCID: https://orcid.org/0000-0002-1175-7469

M.Sc. in Public Administration and Governemnt from the São Paulo School of Corporate Administration of the Getulio Vargas Foundation (FGV EAESP); Coordinator of the Cities and Urban Development Program at the Tide Setubal Foundation, São Paulo - SP, Brazil. E-mail: fabiana.tock@gmail.com

Eduardo José Grin

ORCID: https://orcid.org/0000-0002-0488-8487

Ph.D. in Public Administration and Governemnt from the São Paulo School of Corporate Administration of the Getulio Vargas Foundation (FGV EAESP); Professor in the Department of Public Administration at the São Paulo School of Corporate Administration of the Getulio Vargas Foundation (FGV EAESP), São Paulo - SP, Brazil. E-mail: eduardo.grin@fgv.br

Lauro Gonzalez

ORCID: https://orcid.org/0000-0001-9316-6525

Ph.D. in Corporate Economics from the São Paulo School of Economics (FGV EESP); Coordinator of the Center for Microfinance and Financial Inclusion Studies at the Getulio Vargas Foundation (FGVcemif); Professor at the São Paulo School of Corporate Administration of the Getulio Vargas Foundation (FGV EAESP), São Paulo - SP, Brazil. E-mail: lauro.gonzalez@fgv.br 